\title{
TOXIC PROPERTIES OF SOME DIALKYL AND TRIALKYL TIN SALTS
}

\author{
BY
}

\author{
J. M. BARNES and H. B. STONER
}

From the Toxicology Research Unit, Medical Research Council Laboratories, Woodmansterne Road, Carshalton, Surrey

(RECEIVED FOR PUBLICATION JULY 23, 1957)

Work reported in recent years from this laboratory has outlined the general features of poisoning in animals given di- and trialkyl tin salts (Stoner, Barnes, and Duff, 1955). More detailed accounts of the cerebral oedema produced by triethyl tin in rats (Magee, Stoner, and Barnes, 1957) and the bile duct and liver lesions produced by dibutyl tin salts in rats and mice have also been prepared (Magee and Barnes, 1957; Barnes and Magee, 1958).

A number of alkyl tin salts have been considered for industrial uses. The trialkyl salts are powerful fungicides (van der Kerk and Luijten, 1954) and also have an insecticidal action (Blum and Bower, 1957). The dialkyl tin salts, especially the dibutyl, have been employed as stabilizers in plastic tubing used for a wide variety of purposes. Dibutyl tin salts have also been used as anthelmintics for poultry (Kerr, 1952).

This paper summarizes observations made on 20 alkyl tin compounds given by several routes of administration to different species. Not every compound has been fully studied but data for general comparative purposes have been assembled and particular attention has been paid to those compounds likely to be used commercially.

The biochemical effects of these alkyl tin compounds are also being studied. Some observations have been published (Aldridge and Cremer, 1955; Cremer, 1957) together with a method of analysis (Aldridge and Cremer, 1957).

\section{MATERIALS AND METHODS}

Pure samples of all the tin compounds used in this work were supplied by Dr. van der Kerk, Organisch Chemisch Institut, T.N.O., Utrecht. In addition a supply of recrystallized dibutyl tin dichloride was given to us by Dr. Nancarrow of B.X. Plastics Ltd., and commercial preparations of some compounds were supplied by Pure Chemicals Ltd., and Albright and Wilson Ltd.

The animals used and general methods of administration of drugs are as described earlier (Stoner et al., 1955; Magee, et al., 1957). When Tween 80 or acetone was used as the solvent for intravenous injections the volume injected did not exceed $0 \cdot 1 \mathrm{ml}$. per animal. The lethal doses and their $95 \%$ confidence limits were calculated by the method of Weil (1952).

\section{RESULTS \\ Dialkyl Tin Salts}

Dibutyl Tin Dichloride (D.B.T.C.).-The representative member of this group is dibutyl tin dichloride (D.B.T.C.) and its toxic effects will be described in some detail. Comparisons between other dibutyl tin salts and the dichlorides of other dialkyl tin compounds will be made.

Oral Toxicity in Rats.-A single dose of $50 \mathrm{mg} . / \mathrm{kg}$. D.B.T.C. in arachis oil made a rat ill for 24 to 48 hours after which recovery was usually rapid and complete. Accompanying the general toxic response there was a temporary dilatation of the stomach due to an accumulation of fluid and an inflammatory lesion of the bile ducts. The pathology of the bile duct lesion has been described elsewhere (Magee and Barnes, 1957; Barnes and Magee, 1958).

A single dose of $10 \mathrm{mg}$. $/ \mathrm{kg}$. had no obvious effect but $20 \mathrm{mg}$. $/ \mathrm{kg}$. produced a visible bile duct lesion. The dose response curve resulting from single doses of 50 to $400 \mathrm{mg}$. $/ \mathrm{kg}$. by mouth was flat and it seems probable that much of the single large dose remained unabsorbed (Table 1).

TABLE 1

TOXICITY OF ORAL DIBUTYL TIN DICHLORIDE IN RATS

\begin{tabular}{c|c|c|c}
\hline $\begin{array}{c}\text { Dose } \\
\text { (mg./kg.) }\end{array}$ & Number of Doses & Male & Female \\
\cline { 2 - 3 } 50 & 1 & $0 / 4$ & $0 / 4$ \\
50 & 3 & $5 / 6$ & $0 / 6$ \\
50 & 3 & $4 / 12$ & $4 / 12$ \\
100 & 1 & $0 / 4$ & $0 / 4$ \\
100 & 3 & $5 / 6$ & $6 / 6$ \\
200 & 1 & $1 / 4$ & $1 / 4$ \\
200 & 3 & $6 / 6$ & $5 / 6$ \\
400 & 1 & $4 / 4$ & $2 / 4$ \\
\hline
\end{tabular}

The D.B.T.C. was given in solutions in arachis oil in multiple doses The D.B.T.C. was given in solutions in arachis oil in multiple doses
on successive days, and the mortality is recorded up to 10 days from the first dose expressed as deaths/number treated. 
Successive daily doses of $50 \mathrm{mg} . / \mathrm{kg}$. had a more serious effect (Table 1) and the rats died either from the general toxic effect of the D.B.T.C. or, if they survived for seven days, died later from effects which were secondary to the damage to the bile ducts such as rupture of the duct with bile peritonitis or severe liver injury. The general toxic effects had no special feature. The animal sat quietly with staring coat and usually had some diarrhoea and was generally dirty in appearance. Those rats surviving doses of D.B.T.C. that produced severe bile duct damage with the death of $50 \%$ of the original group recovered completely and have been observed up to 15 months. At necropsy a permanently thickened and shortened bile duct was usually found but it appeared to have been functioning adequately.

Dibutyl tin dichloride has been fed to rats in their diet at levels of 20, 50,75, and 100 p.p.m. for periods up to six months. The effects on growth and food intake are seen in Table 2. Rats on 20 p.p.m. grew normally and showed no lesions at necropsy. At 50 p.p.m. growth and food intake were usually reduced and seven out of 12 rats killed after six months had visible bile duct damage shown by thickening and dilatation of the duct and fibrosis of the pancreas. At 75 and 100 p.p.m. the rats showed a greater depression of growth than those on 50 p.p.m. There were deaths in each group on the higher level during the first four weeks but those surviving this period remained active and well. All survivors killed at six months showed some bile duct damage and this varied considerably in extent.

The administration of D.B.T.C. for these longer periods produced no pathological features that had not been seen in rats receiving single doses of D.B.T.C., and, although lighter in weight, the general condition of the animals was good even when necropsy revealed considerable biliary tract damage.

TABLE 2

EFFECT OF DIBUTYL TIN DICHLORIDE (D.B.T.C.) ADDED TO DIET OF GROWING MALE RATS

\begin{tabular}{|c|c|c|c|c|}
\hline \multirow{2}{*}{$\begin{array}{l}\text { Concentration } \\
\text { of D.B.T.C. } \\
\text { in Diet } \\
\text { (p.p.m.) }\end{array}$} & \multicolumn{2}{|c|}{$\begin{array}{c}\text { Experiment } 1: \\
54 \text { Days }\end{array}$} & \multicolumn{2}{|c|}{$\begin{array}{c}\text { Experiment } 2 \text { : } \\
55 \text { Days }\end{array}$} \\
\hline & $\begin{array}{c}\text { Weight (g.) } \\
\text { Gain } \\
\text { per Rat } \\
\text { (mean } \pm \text { S.D.) }\end{array}$ & $\begin{array}{c}\text { Average } \\
\text { Total Food } \\
\text { Intake } \\
\text { per Rat } \\
\text { (g.) }\end{array}$ & $\begin{array}{c}\text { Weight (g.) } \\
\text { Gain } \\
\text { per Rat } \\
\text { (mean } \pm \text { S.D.) }\end{array}$ & $\begin{array}{c}\text { Average } \\
\text { Total Food } \\
\text { Intake } \\
\text { per Rat } \\
\text { (g.) }\end{array}$ \\
\hline $\begin{array}{r}0 \\
20 \\
50 \\
75 \\
100\end{array}$ & $\begin{array}{c}159 \pm 9 \cdot 7 \\
141 \pm 22 \cdot 7 \\
129 \pm 23 \cdot 5++ \\
93 \pm 10 \cdot 4^{*}\end{array}$ & $\begin{array}{l}723 \\
712 \\
569 \\
513\end{array}$ & $\begin{array}{l}172 \pm 26 \cdot 2 \\
135 \pm 34 \cdot 8 \\
112 \pm 45 \cdot 5^{+} \\
121 \pm 44 \cdot 2^{+}\end{array}$ & $\begin{array}{l}752 \\
577 \\
554 \\
609\end{array}$ \\
\hline
\end{tabular}

$+=$ significantly less than control mean at $P<0.05$ $++=$ significantly less than control mean at $P<0.02$

* = significantly less than control mean at $P<0.01$

The D.B.T.C. was added to diet 41 powder as a solution in arachis oil. All groups contained six rats housed in one cage per group.
The acute effects of two other dibutyl tin saltsthe dilaurate and the di-iso-octyl-thioglycollatewere compared with the dichloride by giving four daily doses of $50 \mathrm{mg}$. $/ \mathrm{kg}$. to groups of four rats. No significant differences in response were observed.

Toxicity in Mice.-This species appeared slightly more susceptible to D.B.T.C. than the rat. Three daily doses of $50 \mathrm{mg}$. $/ \mathrm{kg}$. killed nine of 12 mice and the survivors all had severe liver damage. Bile duct damage was also seen. At $20 \mathrm{mg}$. $/ \mathrm{kg}$. bile duct and liver lesions were produced but the mice were not made seriously ill.

Toxicity in Rabbits.- Repeated daily doses of 25 and $50 \mathrm{mg} . / \mathrm{kg}$. led to the death of five out of eight rabbits within 10 days. No local lesion could be detected either in the biliary system or elsewhere to account for the death of the animals.

Toxicity in Guinea-pigs.-These animals withstood repeated daily doses of 50 to $100 \mathrm{mg} . / \mathrm{kg}$. D.B.T.C. and showed neither a general toxic reaction nor evidence of any biliary tract lesion.

Percutaneous Toxicity in Rats.-Successive daily applications of $10 \mathrm{mg}$. D.B.T.C. $/ \mathrm{kg}$. over a period of 12 days produced a general loss of condition in rats as well as local skin damage with subcutaneous oedema and hyperaemia. Typical bile duct damage was found in these rats indicating that the dibutyl tin had been absorbed.

Rabbits showed more severe local damage in the skin from daily application of D.B.T.C. and their general loss of condition might have been the result of this injury alone. Guinea-pigs, on the other hand, were much more resistant and their skin showed little reaction to daily applications of $120 \mathrm{mg} . / \mathrm{kg}$. on five successive days.

Intraperitoneal Toxicity in Rats.-A dose of $7.5 \mathrm{mg}$. D.B.T.C. $/ \mathrm{kg}$. injected into rats in $0.05 \mathrm{ml}$. of Tween 80 produced intense local irritation within the peritoneal cavity and death in a shock-like condition within a few hours. Tween 80 alone had no such action. The di-laurate had a similar effect indicating that it was the dibutyl tin and not the chloride that was responsible for the local lesion.

Intravenous Toxicity in Rats.-The full potentialities of D.B.T.C. as a toxic substance were studied by intravenous injections. The solvent was Tween 80 . A dose of $5 \mathrm{mg}$. D.B.T.C. $/ \mathrm{kg}$. produced visible bile duct injury within an hour of intravenous injection. As little as $2.5 \mathrm{mg}$. $/ \mathrm{kg}$. produced bile duct injury that was discernible after 24 to 48 hours. These doses made the rat quiet for a few hours but it was not seriously ill. Ten $\mathrm{mg} . / \mathrm{kg}$. resulted in death within 18 hours with an accompanying pulmonary congestion and oedema. 
Rabbits and guinea-pigs were killed by doses of 5 to $10 \mathrm{mg}$. $/ \mathrm{kg}$. They died 24 to 48 hours later with marked pulmonary congestion and oedema but no evidence of biliary tract injury.

Other Dialkyl Tin Salts Studied in Rats.-The toxicity of a number of other dialkyl tin dichlorides was studied and the results are summarized in Table 3 (intravenous), Table 4 (oral), and Table 5 (percutaneous). Particular attention was paid to the dioctyl tin salts when it was learnt that they would make effective substitutes for the more toxic dibutyl tin salts. To supplement the data in the Tables a

TABLE 3

THE INTRAVENOUS TOXICITY OF DIALKYL TIN DICHLORIDES MEASURED BY DEATHS IN RATS

\begin{tabular}{|c|c|c|c|c|c|c|}
\hline \multirow{2}{*}{$\begin{array}{l}\text { Alkyl } \\
\text { Group }\end{array}$} & \multicolumn{4}{|c|}{$\begin{array}{c}\text { Dose } \\
\text { (mg./kg.) }\end{array}$} & \multirow{2}{*}{ Reactions } & \multirow{2}{*}{$\begin{array}{l}\text { Bile Duct } \\
\text { Lesions } \\
\text { in } \\
\text { Survivors }\end{array}$} \\
\hline & 5 & 10 & 20 & 40 & & \\
\hline Methyl & - & 0 & 0 & 2 & $\begin{array}{l}\text { No obvious cause of death } \\
\text { No difference in toxicity } \\
\text { of solution in Tween } \\
\text { and acetone }\end{array}$ & None \\
\hline Ethyl & - & 0 & 1 & 4 & $\begin{array}{l}\text { Deaths } 2-24 \mathrm{hr} \text {. after dose. } \\
\text { No obvious cause }\end{array}$ & Slight \\
\hline Propyl & 0 & 3 & 4 & - & $\begin{array}{l}\text { Deaths usually within } \\
12 \mathrm{hr} \text {. Some had } \\
\text { pleural effusion }\end{array}$ & Moderate \\
\hline Isopropyl & 0 & 0 & 4 & - & $\begin{array}{l}\text { Death } 2-72 \text { hr. Loss of } \\
\text { weight in survivors }\end{array}$ & Moderate \\
\hline Butyl & 0 & 4 & 4 & - & $\begin{array}{l}\text { Death } 1-18 \mathrm{hr} \text {. Consider- } \\
\text { able lung damage }\end{array}$ & Severe \\
\hline Pentyl & 0 & 1 & 4 & - & $\begin{array}{l}\text { Death } 1-18 \mathrm{hr} \text {. Pleural } \\
\text { effusion often marked }\end{array}$ & \\
\hline $\begin{array}{l}\text { Hexyl } \\
\text { Octyl }\end{array}$ & 0 & 2 & 4 & - & Death 2-4 hr. & Moderate \\
\hline Octyl & 0 & 4 & 4 & - & $\begin{array}{l}\text { Deaths usually within } \\
4 \mathrm{hr} \text {. No gross lung } \\
\text { damage }\end{array}$ & None \\
\hline $\begin{array}{l}\text { 2. Ethyl } \\
\text { hexyl }\end{array}$ & 0 & 4 & $2^{*}$ & - & Deaths 4-18 hr. No lesions & None \\
\hline $\begin{array}{l}\text { Trimethyl } \\
\text { hexyl }\end{array}$ & 0 & 4 & $2^{*}$ & - & Deaths 4-18 hr. No lesions & None \\
\hline
\end{tabular}

few notes on each dialkyl tin dichloride compound tested follow:-

Dimethyl.-By intravenous injection this was the least toxic compound tested but on the skin it produced severe superficial damage in the rat and the guinea-pig. By mouth, large doses caused death with generalized weakness. No bile duct lesions were seen in rats.

Diethyl.-The toxic properties of these salts have been described earlier (Stoner et al., 1955). Additional information from these experiments is that solutions applied to the skin produced a superficial necrosis accompanied by a more deep-seated inflammation. Damage to the bile ducts was noted

TABLE 5

THE TOXICITY OF DIALKYL TIN DICHLORIDES APPLIED PERCUTANEOUSLY TO MALE RATS

\begin{tabular}{|c|c|c|}
\hline $\begin{array}{l}\text { Alky } \\
\text { Grou }\end{array}$ & Skin Lesion and General Reactions & $\begin{array}{l}\text { Bile Duct } \\
\text { Lesion }\end{array}$ \\
\hline Methyl & $\begin{array}{l}\text { Necroses of superficial layers of skin with } \\
\text { black eschar formation. No deep-seated } \\
\text { inflammation. Slight weight loss. }\end{array}$ & None \\
\hline Ethyl & $\begin{array}{l}\text { Slight superficial necrosis with patchy eschar. } \\
\text { Generalized deep-seated oedema and sub- } \\
\text { cutaneous infla nmation. }\end{array}$ & None \\
\hline Propyl & $\begin{array}{l}\text { Lost weight and appeared generally ill. } \\
2 / 3 \text { died. White patchy necrosis of skin } \\
\text { with deeper inflammation and oedema. }\end{array}$ & Slight \\
\hline Isopropyl & $\begin{array}{l}\text { Some weight loss. Not as ill as after propyl. } \\
\text { Dry necrosis of skin. No eschar. Deeper } \\
\text { oeder.a and inflammation. }\end{array}$ & Modera \\
\hline Butyl & $\begin{array}{l}1 / 3 \text { died. Others less affected. Little super- } \\
\text { ficial damage to skin but some oedema of } \\
\text { subcutaneous tissues. }\end{array}$ & Marked \\
\hline Pentyl & $\begin{array}{l}\text { Rats became very irritable. No obvious skin } \\
\text { lesions or subcutaneous oedema. Dark } \\
\text { adrenals in one rat. }\end{array}$ & Slight \\
\hline $\begin{array}{l}\text { Hexy } \\
\text { Octyl }\end{array}$ & $\begin{array}{l}\text { No loss of weight. No skin lesion. } \\
\text { No loss of weight. No skin lesion. }\end{array}$ & $\begin{array}{l}\text { None } \\
\text { None }\end{array}$ \\
\hline
\end{tabular}

The tin salts, $80 \mathrm{mg} . / \mathrm{kg}$., were dissolved in $0.1 \mathrm{ml}$. dimethylphthalate applied on five successive days to groups of three rats. Skin clipped. Rats observed for 12 days and at necropsy the skin lesion and condition of the bile duct were examined.

TABLE 4

THE COMPARATIVE ORAL TOXICITY OF DIALKYL TIN DICHLORIDES

\begin{tabular}{|c|c|c|c|}
\hline Alkyl Group & $40 \mathrm{mg} . / \mathrm{kg}$. & $80 \mathrm{mg} . / \mathrm{kg}$. & $160 \mathrm{mg} . / \mathrm{kg}$. \\
\hline $\begin{array}{l}\text { Methyl } \\
\text { Ethyl } \\
\text { Propyl }\end{array}$ & $\begin{array}{l}\text { No loss of weight. No bile duct lesion. } \\
\text { No loss of weight. No bile duct lesion. } \\
\text { No loss of weight. No bile duct lesion. }\end{array}$ & $\begin{array}{l}\text { No loss of weight. No bile duct lesion. } \\
\text { One cied. Lung congestion. } \\
\text { One unaffected. No bile duct lesion. } \\
\text { One ill and killed fifth day. No lesion. } \\
\text { One unaffected. No bile duct lesion. }\end{array}$ & $\begin{array}{l}\text { Both died on fourth day with marked } \\
\text { weakness. No bile duct lesion. } \\
\text { Both died on fourth day. No lesions (see } \\
\text { text). } \\
\text { One died second day. Pulmonary con- } \\
\text { gestion. One lost weight. Recovered. } \\
\text { Slight bile dut lesion. }\end{array}$ \\
\hline & $\begin{array}{l}\text { No loss of weight. Very slight bile } \\
\text { duct lesion. }\end{array}$ & $\begin{array}{l}\text { Slight loss of weight. Mild bile duct } \\
\text { lesion. }\end{array}$ & \\
\hline $\begin{array}{l}\text { Butyl } \\
\text { Pentyl }\end{array}$ & $\begin{array}{l}\text { One died. Bile duct lesion. One lost } \\
\text { weight. } \\
\text { Both lost weight. Some bile duct } \\
\text { damage. }\end{array}$ & $\begin{array}{l}\text { Two died. One had severe liver lesion. } \\
\text { Both had bile duct lesion. } \\
\text { One died fifth day. No necropsy. One } \\
\text { lost weight. Adrenals red. Bile duct } \\
\text { lesion. }\end{array}$ & $\begin{array}{l}\text { Both very ill and lost weight. Severe } \\
\text { bile duct lesions. } \\
\text { Both lost weight. Adrenals very dark at } \\
\text { nzcropsy. Slight bile duct lesion. }\end{array}$ \\
\hline Hexyl & $\begin{array}{l}\text { One lost weight and died. No bile duct } \\
\text { lesion. One unaffected. }\end{array}$ & $\begin{array}{l}\text { Both lost weight and then recovered. } \\
\text { Adrenals very dark at necropsy. No } \\
\text { bile duct lesion. }\end{array}$ & $\begin{array}{l}\text { Both lost weight and one died. No bile } \\
\text { duct lesion. }\end{array}$ \\
\hline $\begin{array}{l}\text { Octyl } \\
\text { 2. ethyl hexyl }\end{array}$ & $\begin{array}{l}\text { No loss of weight or bile duct lesion. } \\
50 \mathrm{mg} . / \mathrm{kg} \text {. No ill effect. }\end{array}$ & $\begin{array}{l}\text { No loss of weight or bile duct lesion. } \\
100 \mathrm{mg} \text {. } / \mathrm{kg} \text {. No loss of weight or bile } \\
\text { duct lesion. }\end{array}$ & $\begin{array}{l}\text { One lost weight but no cause found. } \\
200 \mathrm{mg} . / \mathrm{kg} \text {. No ill effect. }\end{array}$ \\
\hline
\end{tabular}

Oral doses were given to pairs of female rats on normal diet observed for 10 days from first dose; $40 \mathrm{mg} . / \mathrm{kg}$. given on first and fourth days $80 \mathrm{mg} . \mathrm{kg}$. on first and fourth days except di-hexyl given only on first day, $160 \mathrm{mg}$. $/ \mathrm{kg}$. given on first day only except dibutyl and dioctyl given also on fourth day. 
in all survivors of the intravenous toxicity test, and single oral doses of $200 \mathrm{mg}$. $/ \mathrm{kg}$. produced typical damage to the bile ducts and dilatation of the stomach in $\mathbf{4 8}$ hours.

Di-n-propyl.- This was more toxic than the dimethyl or diethyl salt and after intravenous injection death was accompanied by pulmonary oedema. Percutaneously, it produced a generalized injury to the skin with deep-seated inflammation and oedema but less superficial necrosis than the dimethyl and diethyl salts. Bile duct lesions were produced.

Di-iso-propyl.-This salt was very similar to the di-n-propyl though bile duct lesions were more conspicuous after oral or percutaneous application.

Di-n-pentyl.-This salt was less toxic than the dibutyl by intravenous injection but also produced pulmonary oedema. It caused very little injury to the skin but bile duct lesions were seen after administration by all routes. In several rats dying after di-n-pentyl tin dichloride by mouth dark red adrenals were seen at necropsy. Microscopically the lesion was a haemorrhagic infiltration disrupting the gland. The lesion could not be consistently reproduced.

Di-n-hexyl.-Though more toxic by intravenous injection than the di-n-pentyl, the di-n-hexyl was less toxic by mouth or percutaneously. It produced bile duct lesions but only very slight injury to the skin. Again, adrenal damage was occasionally seen but could not be regularly produced.

Six rats given doses of $40 \mathrm{mg} . / \mathrm{kg}$. on four successive days by mouth all lost weight and one died. They continued to lose weight for 12 days but at necropsy no cause for this could be discovered.

Di-n-octyl.-Although as toxic as the dibutyl salt by intravenous injection the dioctyl salts were completely non-toxic by mouth or percutaneously. The cause of death in animals given intravenous doses was not clear. More extensive tests confirmed the non-toxicity of the dioctyl tin salts given by mouth to mice, guinea-pigs, and rabbits in doses up to $400 \mathrm{mg}$. $/ \mathrm{kg}$. for three to four successive days. No ill effects of any kind were observed in any species. Groups of six young rats were given food containing 100 and 200 p.p.m. dioctyl tin dichloride for four months. They grew normally and were free from any lesions when killed.

Bis-2-ethyl hexyl (Di-iso-octyl) Tri-methyl hexyl (Di-iso-nonyl).-These salts had a similar intravenous toxicity to the di-n-octyl salts and were apparently completely non-toxic by mouth or applied to the skin.

\section{Trialkyl Tin Salts}

The members of this group of compounds that have been most extensively studied are the salts of triethyl tin and a detailed account of their toxic properties is given elsewhere (Stoner et al., 1955; Magee et al., 1957).

Triethyl tin acetate is soluble in water to the extent of about $3 \%$ and is equally toxic to rats by mouth or by intravenous injection (Table 6). The

TABLE 6

THE TOXICITY OF SINGLE DOSES OF TRIALKYL TIN ACETATE

\begin{tabular}{|c|c|c|}
\hline Alkyl Group & \multicolumn{2}{|c|}{$\begin{array}{c}\text { LD50 } \\
\text { (mg. Acetate per kg. } \\
\text { Body Weight) }\end{array}$} \\
\hline $\begin{array}{l}\text { Methyl (aqueous solution) } \\
\text { Ethyl } \\
+ \text { +Ethyl } \\
++ \text { Ethyl } \\
\text { N-propyl } \\
\text { Iso-propyl } \\
\text { N-butyl } \\
\text { N-hexyl } \\
\text { N-octyl }\end{array}$ & $\begin{array}{r}9 \cdot 1 \\
4 \cdot 0 \\
4 \cdot 2 \\
7 \cdot 6 \\
118 \cdot 3 \\
44 \cdot 1 \\
380 \cdot 2 \\
1000^{*} \\
>1000^{* *}\end{array}$ & $\begin{array}{r}(7.0-11 \cdot 8) \\
(2.9-55.5) \\
(3.2-55.2) \\
(6.4-\quad 9 \cdot 0) \\
(98.3-142.4) \\
(36.1-53.9) \\
(238.1-607.3)\end{array}$ \\
\hline
\end{tabular}

+ Intravenous route.

++ Male rats approximately $200 \mathrm{~g}$. body weight.

* Two deaths in four rats given this dose.

** No deaths in four rats given this dose.

Except where otherwise shown the compounds were dissolved in arachis oil and given by mouth to female rats (approximately $200 \mathrm{~g}$. body weight). The groups were kept for at least six and up to 21 weeks after administration and the LD50 calculated by Weil's (1952) method. The $95 \%$ confidence limits are shown in parentheses.

salient features of poisoning by a dose just exceeding the LD50 was an immediate period resembling mild anaesthesia lasting one to two hours followed by recovery. The rat, however, remained quiet and became progressively more ill with increasing muscular weakness and died within two to five days. The pathological lesion was oedema of the white matter of the central nervous system, but it is uncertain whether this alone accounted for the striking muscular weakness. A similar condition in rats may be produced by feeding a diet containing 10 to 20 p.p.m. triethyl tin hydroxide. Other species react somewhat differently to single doses. Rabbits show the initial mild anaesthesia and recover, but die within 24 hours after a series of convulsions of moderate severity. Hens tolerate its oral administration but are very sensitive to intravenous doses. Death may follow almost instantaneously or they recover completely after a few hours' unconsciousness.

The effects of other trialkyl tin salts on rats will now be briefly described. The LD50 for oral administration is given in Table 6. The reaction of rats to the intravenous injection of the higher homologues was very irregular in that some animals showed no reaction at all to a dose that was rapidly fatal to another rat of similar sex and age injected 
immediately afterwards. For this reason an attempt to establish intravenous LD50s for each compound was not pursued. An effect apparently related to the different solvents-acetone and Tween 80 -was noted in some cases. The solvent-water or acetone - did not influence the response of rats to triethyl tin acetate.

Trimethyl Tin Acetate.-As with the ethyl analogue the toxic dose by mouth was similar to that by intravenous injection. A characteristic picture was produced by either oral dosage or intravenous injection. There was an initial period of weakness with some degree of catatonia lasting several hours. After 24 hours generalized mild and continuous tremors developed with a pronounced irritability of the rats; a peculiar sparring among cage-mates might take place intermittently for two to three days. If the tremors were severe the animal would be prone in the cage with its tail held erect and its muscles in continuous tremor. Death might be delayed for up to eight days and some tremors might persist for the whole of that time. With very large oral doses $(65 \mathrm{mg} . / \mathrm{kg}$. and above) there was generalized weakness and prostration as after triethyl tin.

Tri-n-propyl Tin Acetate.-A fatal oral dose produced death in two to four days and the rats had muscular weakness and an unsteady gait and were obviously ill. By intravenous injection the lethal dose was considerably less $(24 \mathrm{mg}$. $/ \mathrm{kg}$. killed seven out of eight rats). This always took place within 18 hours of the injection and was preceded by a progresive weakness of rapid onset. However, even the profound weakness seen in rats dying within 20 minutes was not accompanied by a true coma. Those surviving an intravenous injection for 24 hours had always recovered completely from any weakness they had displayed earlier.

Tri-iso-propyl Tin Acetate.-This was more toxic than tri-n-propyl tin both by mouth and by intravenous injection. A dose of $12 \mathrm{mg}$. $/ \mathrm{kg}$. intravenously killed eight of 12 rats. They developed a weakness of sudden onset after intravenous injection which lasted up to four hours. At $3 \mathrm{mg}$. $/ \mathrm{kg}$. recovery was complete within 24 hours. At higher doses there might be a sudden collapse and death within 10 minutes or a severe weakness only partly recovered from at 24 hours. By mouth the effects were of slower onset, and might last for up to eight days before the animal died. They walked unsteadily with a humped gait and general muscular weakness. Irritability was occasionally seen. A similar difference between the toxicities of tetra- $n$ propyl tin and tetra-iso- propyl tin has been reported by Caujolle, Lesbre, Meynier, and Blaizot (1955).
Tri-n-butyl Tin Acetate.-By intravenous injection this was more toxic than the tri-iso-propyl compound but death always took place within 10 minutes of the injection. Only an occasional rat of the 74 tested by this route of injection showed a persistent weakness such as was seen after tri-propyl tin salts.

By mouth tributyl tin acetate was much less toxic than the tri-propyl compounds and those receiving a fatal dose died within one to two days with the usual signs of weakness and a humped gait. In one group of four rats given $380 \mathrm{mg} . / \mathrm{kg}$., all became acutely ill and one died after 24 hours. The other three recovered and began to gain weight. After five weeks they again began to lose weight, became ill, and died six to seven weeks after injection. No cause of death could be established. In acute toxicity experiments on a series of tetra-alkyl tin compounds, Caujolle, Lesbre, and Meynier (1954a) emphasized the need for continuing such experiments for a considerable time in order to determine the full toxicity of the compound. In our experiments these were the only rats which died more than eight days after the administration of a single dose of any of the trialkyl tin compounds. Furthermore, these observations could not be repeated and rats survived larger doses of tributyl tin acetate without showing any such delayed effects.

Prolonged administration of tributyl tin was studied on three groups of 12 rats given 25,50 , and 100 p.p.m. tributyl tin acetate in their diet for three months. The growth curves are shown in Fig. 1. They showed slightly impaired health on feeding

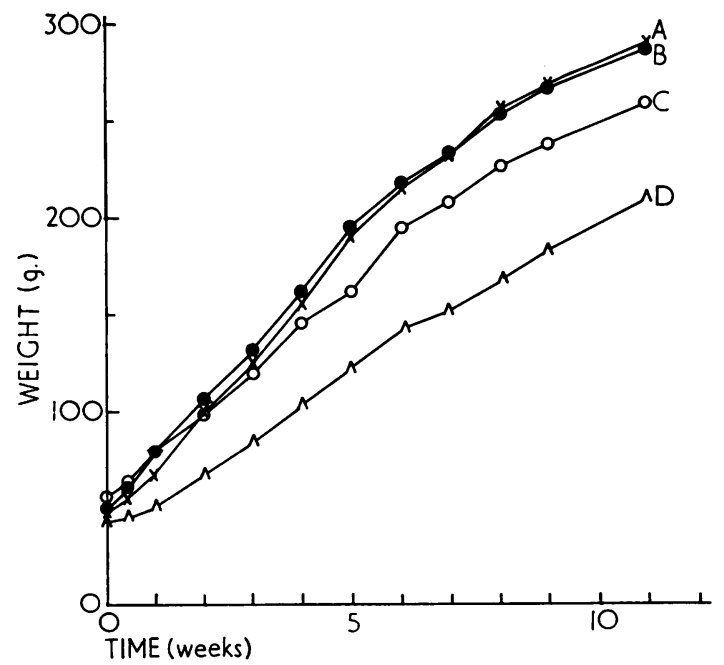

FIG. 1.-The growth curve of rats on diets containing tributyl tin acetate.

$A=$ Control, $B=25$ p.p.m., $C=50$ p.p.m., $D=100$ p.p.m. 
50 p.p.m. and were more severely affected at 100 p.p.m. In this group two rats died during the first three weeks but the other animals recovered and were outwardly healthy when killed.

At necropsy four out of 11 rats on the highest level showed some degree of bile duct injury typical of dibutyl tin poisoning. No bile duct injury was seen in the other groups at the end of the experiment. The material used in the test was analysed and found to contain not more than $0.5 \%$ dibutyl tin. In view of these results, experiments are in hand to study the possible conversion of tributyl tin to dibutyl tin in vivo. The brain and spinal cord water content was also measured and at the highest level of intake the water content of the spinal cord was significantly increased (Table 7), but the increase was not large enough to be visible in histological sections.

To a single oral dose of tributyl tin acetate mice were as sensitive as rats. In the dose range 100 to $200 \mathrm{mg}$. $/ \mathrm{kg}$. seven out of 32 died. All the animals were ill and lost weight for several days. The rabbits and the guinea-pigs were more sensitive and at a dose of $40 \mathrm{mg}$. $/ \mathrm{kg}$. some animals died. They showed evidence of intense irritation of the alimentary tract, particularly of the caecum.

Solutions of tributyl tin acetate in alcohol or in arachis oil applied to the skin of rats, rabbits, and guinea-pigs caused a superficial encrustation but no deep-seated inflammation.

\section{TABLE 7}

EFFECT OF FEEDING TRIBUTYL TIN ACETATE IN DIET TO MALE RATS FOR 13 WEEKS ON PERCENTAGE WATER TO MALE RANTENT OF BRAIN AND SPINAL CORD

\begin{tabular}{|c|c|c|c|}
\hline \multirow{2}{*}{ Treatment } & \multirow{2}{*}{$\begin{array}{l}\text { No. of } \\
\text { Rats }\end{array}$} & \multicolumn{2}{|c|}{$\%$ Water Content } \\
\hline & & Brain & Spinal Cord \\
\hline Controls & 5 & $78 \cdot 2 \pm 0 \cdot 3$ & $70 \cdot 4 \pm 0.5$ \\
\hline $\begin{array}{l}25 \text { p.p.m. tributyl tin acetate } \\
50 \text { p.p.m. tributyl tin acetate } \\
100 \text { p.p.m. tributyl tin acetate }\end{array}$ & $\begin{array}{l}5 \\
5 \\
5\end{array}$ & $\begin{array}{l}77 \cdot 8 \pm 0 \cdot 2 \\
78 \cdot 0 \pm 0 \cdot 3 \\
78 \cdot 7 \pm 0 \cdot 4\end{array}$ & $\begin{array}{l}70 \cdot 8 \pm 1 \cdot 6 \\
70 \cdot 5 \pm 0 \cdot 7 \\
72 \cdot 6 \pm 1 \cdot 0^{+}\end{array}$ \\
\hline
\end{tabular}

Tri-hexyl Tin Acetate.-After intravenous injection of a lethal dose $(6$ to $12 \mathrm{mg} . / \mathrm{kg}$.) rats slowly became quieter and ruffled and after four to eight hours showed respiratory embarrassment and died with mild convulsions. At necropsy there was gross pulmonary oedema and pleural effusion similar to that seen in rats poisoned with $\alpha$-naphthyl thiourea (Richter, 1946). No weakness or unsteadiness typical of poisoning by the lower homologues was noted in these rats. All four rats receiving $100 \mathrm{mg} . / \mathrm{kg}$. by mouth became ill and two died. This illness was of a more general type, again lacking the distinctive features of poisoning by the lower homologues. No naked-eye changes were seen at necropsy.
Trioctyl Tin Acetate.-This compound produced no effect at all in doses up to $48 \mathrm{mg}$. $/ \mathrm{kg}$. intravenously or $1,000 \mathrm{mg} . / \mathrm{kg}$. by mouth.

\section{PATHOLOGICAL FINDINGS}

Naked-eye examination of rats dying after oral doses showed nothing abnormal. After intravenous injection moderate pulmonary congestion was sometimes seen in fatal poisoning by the tri-propyl and tri-butyl tin salts, but it was not enough to account for death. The pulmonary oedema and pleural effusion were almost certainly the cause of death after intravenous trihexyl tin salts.

The oedema of the white matter of the central nervous system produced by tri-ethyl tin salts has been described elsewhere (Magee et al., 1957).

The estimation of brain and spinal cord water was carried out in rats dying after oral doses of certain other tri-alkyl tin salts and the results are given in Table 8.

TABLE 8

EFFECT OF TRIALKYL TIN COMPOUNDS ON WATER CONTENT OF BRAIN AND SPINAL CORD OF FEMALE RATS IN WEIGHT RANGE 190-205 g.

\begin{tabular}{|c|c|c|c|c|c|}
\hline \multirow{2}{*}{ Compound } & \multirow{2}{*}{$\begin{array}{l}\text { Oral Dose } \\
\text { Acetate } \\
\text { (mg./kg.) }\end{array}$} & \multirow{2}{*}{$\begin{array}{c}\text { Inter- } \\
\text { val } \\
\text { (days) }\end{array}$} & \multirow{2}{*}{\begin{tabular}{|c|} 
No. \\
of \\
Rats
\end{tabular} \mid} & \multicolumn{2}{|c|}{$\%$ Water Content } \\
\hline & & & & Brain & Spinal Cord \\
\hline $\begin{array}{l}\text { (Controls) } \\
\text { Trimethyl } \\
\text { Trimethyl } \\
\text { Triethyl } \\
\text { Tri- } n \text {-propyl } \\
\text { Tri-iso-propyl } \\
\text { Tri- } n \text {-butyl } \\
\text { Tri-n-butyl }\end{array}$ & $\begin{array}{r}- \\
20 \\
30 \\
8 \\
200 \\
100 \\
450 \\
600\end{array}$ & $\begin{array}{l}- \\
2 \\
2 \\
2 \\
3 \\
2 \\
3 \\
3 \\
\end{array}$ & $\begin{array}{l}6 \\
4 \\
3 \\
5 \\
4 \\
5 \\
4\end{array}$ & $\begin{array}{l}77 \cdot 2 \pm 0.39 \\
76 \cdot 8 \pm 0.26 \\
77.0 \pm 0.26 \\
79 \cdot 1 \pm 0.26++ \\
78.8 \pm 0.39++ \\
79.9 \pm 0.82++ \\
77.2 \pm 0.48 \\
78.4\end{array}$ & $\begin{array}{l}69 \cdot 0 \pm 0.39 \\
69 \cdot 4 \pm 0.17 \\
69 \cdot 1 \pm 0.89 \\
74 \cdot 1 \pm 0.49++ \\
72.0 \pm 1 \cdot 14++ \\
75 \cdot 5 \pm 1 \cdot 77++ \\
68 \cdot 1 \pm 1.52 \\
\end{array}$ \\
\hline Tri-n-butyl & 300 & $1\}$ & 4 & $78.4 \pm 0.69+$ & $71.4 \pm 1.62+$ \\
\hline
\end{tabular}

$++=$ Significantly different from the controls at $P<0.001$.
$+=$ Significantly different from the controls at $P<0.01$.

Triethyl tin was the most active of these compounds and the activity of the higher homologues was of the same order as their toxicity. In spite of the profound effects produced by trimethyl tin salts on the central nervous system as judged by the behaviour of the animals, no oedema of the central nervous system was produced by trimethyl tin salts.

\section{DISCUSSION}

The lower dialkyl tin salts act upon biological systems in vitro in a similar manner to arsenicals (Aldridge and Cremer, 1955) and in neither case is the exact mechanism by which the poisoned animal is killed completely understood. This general toxic effect is counteracted in both cases by B.A.L.

Dimethyl and diethyl tin salts produce severe superficial injury to rodent skin but it is not known whether they would act as vesicants for human skin. Bile duct damage can be produced with the diethyl 
but not the dimethyl tin salts but is more readily elicited by the higher homologues which produce a less striking injury to the skin. While lewisite (2-chlorovinyldichloroarsine) damages the biliary system of guinea-pigs but not of rats (Cameron, Carleton, and Short, 1946) the converse is true for the dialkyl tin salts.

Hitherto the chief industrial interest has been in the dibutyl tin salts which have been added to certain plastics as stabilizers. There are no published data to indicate whether or not these compounds would leach out of a finished plastic tube or wrapping into the liquid or food in contact with such material. From our study of the effects of dibutyl tin dichloride in the diet the highest harmless level for the rat appears to be about 20 p.p.m. Using the conventional 100 -fold safety factor a safe level in food should certainly not exceed 0.2 p.p.m. Extrapolation of data from rats to man in this case is particularly difficult because it is known that the guinea-pig and hen are much less susceptible to the toxic action of dialkyl tin salts by mouth while the mouse is possibly rather more susceptible than the rat. Although it is difficult to draw definite conclusions from the French cases of alkyl tin poisoning (see below), they do show that man is affected by these compounds.

The problem of toxic residues of dialkyl tin stabilizers used in plastics which may come into contact with food may be resolved if the dioctyl or a similar higher analogue is used. These have no demonstrable toxicity to rats, rabbits, or guinea-pigs when given by mouth or applied to the skin in large doses nor do they have any action on the biochemical systems studied in vitro (W. N. Aldridge, personal communication).

The trialkyl tin compounds have been studied in considerable detail because their mode of action appears to be distinct from that of other well-known metabolic poisons. In high dilution in vitro they inhibit oxidative phosphorylation by mitochondria (Aldridge and Cremer, 1955). Similarly, when slices are prepared from triethyl-tin-treated rats only the $\mathrm{O}_{2}$ uptake of the brain slices is impaired although most of the triethyl tin is concentrated in the liver and erythrocytes. In the whole animal the pharmacological and pathological effects are practically confined to the nervous system (Stoner, et al., 1955; Magee, et al., 1957), but alterations in the metabolism of phosphate compounds can be demonstrated both there and in the liver (Stoner and Threlfall, 1958). The observations made so far seem to indicate a failure in the utilization of chemical energy rather than a disturbance in its production in mammals poisoned by triethyl tin, but the mode of action of the trialkyl tin compounds is not known.
From the practical point of view it is important to remember that the action of triethyl tin upon the central nervous system is reversible in the rat (Magee, et al., 1957). No permanent brain cell damage or tract demyelination is produced as in the case of the alkyl mercury derivatives (Hunter, Bomford, and Russell, 1940). This may be an important point to bear in mind when comparing the possible hazards in handling the two groups of compounds as fungicides.

Triethyl tin has a good fungicidal activity and is also very toxic to animals. Tributyl tin appears to be an equally good fungicide (van der Kerk and Luijten, 1954) but is much less toxic to rats. Fed to rats over a period of three months tributyl tin acetate produced no symptoms at a level of 50 p.p.m. in the food though at 100 p.p.m. some oedema of the central nervous system was produced. Studies in vitro demonstrate little difference in the power of triethyl and tributyl tin to inhibit oxidative phosphorylation (W. N. Aldridge, personal communication). This may explain why both have fungicidal activity. The lesser toxicity of the tributyl tin salts cannot yet be explained but may be due to differences in the rate of absorption and ultimate distribution in the body. Preliminary observations point to species differences in the sensitivity to these salts given by mouth. The higher homologues such as trioctyl tin acetate are inactive as fungicides and without toxic effect on the whole animal or those mammalian biochemical preparations which have been studied in vitro.

Up to the present the only reports of human poisoning from alkyl tin compounds have come from France where a preparation alleged to be diethyl tin diiodide was widely sold for a time as a treatment for skin diseases. Although there were many fatalities and many non-fatal cases there have been no reports of long-term disabilities such as occur after poisoning by alkyl mercury derivatives. Even severe cases of poisoning do not appear to have been necessarily fatal (Rouzaud and Lutier, 1954). Although the main tin ingredient of the preparation was in the dialkyl form the main feature of the poisoned cases was cerebral oedema which in animals is characteristic of poisoning by trialkyl tin. This might indicate that trialkyl tin was present as an impurity, in which case it would seem that man is very sensitive to the action of this form of tin. The hazards that might accompany the use of trialkyl tin compounds as fungicides in agriculture cannot be accurately gauged. While B.A.L. would probably be an effective remedy for poisoning by dialkyl tin compounds no rational therapy can yet be suggested for poisoning by trialkyl tin salts.

From the toxicological point of view the tetra- 
alkyl tin compounds can be considered to behave in an analogous way to their trialkyl counterparts (Jolyet and Cahours, 1869; Lecoq, 1954; Stoner, et al., 1955; Caujolle, et al., 1955; Caujolle, et al., 1954a, b). This may be explained by their conversion to the trialkyl derivatives in the body as this has recently been demonstrated for tetraethyl tin in vitro by Cremer working in this laboratory.

\section{SUMMARY}

The toxicity of a series of di- and trialkyl tin compounds has been studied after their administration by different routes in a number of species.

There is a striking difference in the response to the two groups of compounds. The dialkyl tin compounds cause a generalized illness with damage to the biliary tract as the main pathological feature. The trialkyl compounds act on the central nervous system where the majority of them produce an interstitial oedema.

We are grateful to Mr. C. R. Kennedy for his technical assistance particularly in the feeding experiments.
We wish to thank Mr. W. R. Lewis of the Tin Research Institute for his help in arranging supplies of some of the materials used in these experiments.

\section{REFERENCES}

Aldridge, W. N., and Cremer, J. E. (1955). Biochem. J., 61, 406. Analyst, 82, 37.

Barnes, J. M., and Magee, P. N. (1958). J. Path. Bact. In press. Blum, M. S., and Bower, F. A. (1957). J. econ. Ent., 50, 84. Cameron, G. R., Carleton, H. M., and Short, R. H. D. (1946) J. Path. Bact., 58, 411 .

Caujolle, F., Lesbre, M., and Meynier, D. (1954a). C.R. Acad. Sci. (Paris), 239, 1091.

,$- L$, (1954b). Ibid., 239, 556.

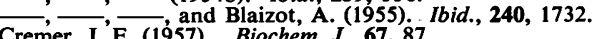

Hunter, D., Bomford, R. R., and Russell, D. S. (1940). Quart. J. Med., n.s., $9,193$.

Jolyet, F., and Cahours, A. (1869). C.R. Acad. Sci. (Paris), 68, 1276.

Kerk, G. J. M. van der, and Luijten, J. G. A. (1954). J. appl. Chem., Kerr, 314

Kerr, K. B. (1952). Poult. Sci., 31, 328.

Lecoq, R. (1954). C.R. Acad. Sci. (Paris), 239, 678.

Magee, P. N., and Barnes, J. M. (1957). Ned. T. Geneesk. In press. , Stoner, H. B., and Barnes, J. M. (1957). J. Path. Bact., 73, 107 Richter, C. P. (1946). Proc. Soc. exp. Biol. (N.Y.), 63, 364.

Rouzaud, M., and Lutier, J. (1954). Presse med., 62, 1075 . 10, 16.

and Threlfall, C. J. (1958). In preparation.

Weil, C. S. (1952). Biometrics., 8, 249.

\section{THE OCTOBER (1957) ISSUE}

The October (1957) issue contains the following papers:-

Experimental Studies on the Relative Importance of Concentration and Duration of Exposure to Dust Inhalation. By B. M. Wright.

The Effect of the Use of Calcined Alumina in China Biscuit Placing on the Health of the Workman. By A. Meiklejohn and E. Posner.

Air Pollution in Diesel Bus Garages. By B. T. Commins, R. E. Waller, and P. J. Lawther.

Observations on Urinary Cadmium and Protein Excretion in Men Exposed to Cadmium Oxide Dust and Fume. By J. C. Smith and J. E. Kench.

Chemical and Histological Post-mortem Studies on a Workman Exposed for Many Years to Cadmium Oxide Fume. By J. C. Smith, J. E. Kench, and J. P. Smith.

An Investigation into the Acute Respiratory Reaction to the Inhalation of Tamarind Seed Preparations. By Peter G. Tuffnell and I. Dingwall-Fordyce.

A Review of 102 Cases of Beat Conditions of the Knee. By W. B. Roantree.

Ventilation of Impermeable Clothing. By G. S. Christie, J. P. Gleeson, W. G. Jowett, and A. S. Wright.

Absence and the Physical Conditions of Work. By R. D. Shepherd and J. Walker.

Azo Dyes and Heinz Bodies. By Philip Rofe.

Experience of Pulheems in the 1952 Army Intake. By S. Rosenbaum.

The Efficiency of Various Liquid Impinger Samplers in Bacterial Aerosols. By K. R. May and G. J. Harper.

Miscellanea:

The Range of Vision Permitted by Protective Goggles. By J. P. Bull.

Book Review.

Index.

A number of copies are still available and may be obtained from the Publishing Manager, British Medical Association, Tavistock Square, W.C.1, price 12s. 6d. 